\title{
Detection Moleculer of Putative 18S rRNA Gen Protozoa Trichodina sp. Infected Larvae Gurami (Osphronemus gouramy L) in Balai Benih Ikan Kutasari Purbalingga Central Java
}

\author{
Rokhmani, Daniel Joko Wahyono, Lilis Mulyani \\ Faculty of Biology, Universitas Jenderal Soedirman, Indonesia \\ Jalan dr. Suparno 63 Purwokerto 53122 \\ Email : rokhmanitatiek@gmail.com
}

Rekam Jejak Artikel:

Diterima : 19/02/2021

Disetujui : 10/04/2021

\begin{abstract}
Trichodina spp. are ectoparasitic pathogens of ciliata group that commonly infect both freshwater and marine fish, including gouramy fish. As a result of infection of Trichodina spp. this will lead to inhibition of fish growth and decreased fish production, resulting in low fish selling value. The rate of occurrence of Trichodina spp. that infects gurami can reach $100 \%$. Research has been conducted to determine which one Trichodina spp. Protozoa that infects the gouramy seeds of BBI (Fish Seed Center) Kutasari Purbalingga following detection of 18S RNA gene. Gene detection method used in this research is Polymerase Chain Reaction (PCR) is a technique of DNA synthesis and amplification in vitro. This research is done following these methodes: (1) sampling of Gurami fish with purposive sampling which obtained from BBI Kutasari Purbalingga, (2) isolation of Trichodina spp., (3). Preparation of Trichodina spp. sample and its identification, and (4). Molecular character obervation following detection of $18 \mathrm{~S}$ rRNA gene. This study obtained $10 \%$ percentage of detection of 18S rRNA genes of the species of Trichodina paraheterodentata that infect on the gouramy fish of Purbalingga. The percentage rate of detection of these genes is low when compared with the results of the detection of $18 \mathrm{~S}$ rRNA Trichodina paraheterodentata gene that infects gouramy fish in Banjarnegara.

Keywords: Trichodina spp., T. paraheterodentata, Gurami Fish, Gen 18s RNA.
\end{abstract}

\section{INTRODUCTION}

Trichodina spp. is a pathogenic ectoparasite from the ciliate group that commonly attacks freshwater and marine fish (Margolis \& Arthur, 1979). This ectoparasite is $\pm 50 \mathrm{~nm}$ in size, round in shape, with a bell-shaped lateral side, has a denticle ring for attachment and has cilia around its body. Ectoparasites are known to cause mortality of goldfish (Cyprinus carpio), Mujair fish (Oreochromis mossambicus) in South Africa (Van et al., 1984; Dana et al., 2002), Rainbow trout (Salmo gairdneri) and Salmon (Salmo salar) by attacking or infecting the skin and gills of fish in the UK (Mc Ardle, 1984 in Dana et al., 2002). One type of fish is often infected by Trichodina spp. is gouramy. The disadvantages of ectoparasite infection are not as big as those caused by infection with other organisms such as viruses and bacteria, but ectoparasite infection can be one of the predisposing factors for infection with more dangerous pathogenic organisms (Rokhmani, 2009).

Trichodina paraheterodentata was first identified by Duncan (1977), and has been known to attack Mujair fish (Oreochromis mossambicus) (Duncan 1977; Van As \& Basson 1986; BondadReantaso \& Arthur 1989), Tilapia (Tilapia rontroli), Sepat (Trichogaster tricopterus) (Bondad-Reantaso \& Arthur 1989), Tilapia (Oreochromis niloticus) (Natavidad et al., 1986) and Goldfish (Cyprinus carpio) (Basson et al., 1983; Van As et al., 1984; Albaladejo \& Arthur 1989).
Gouramy fish (Osphronemus gouramy Lacepede) is a type of freshwater fish from the Osphronemidae family and one of the types of freshwater cultivated fish that is widely developed by farmers. Gouramy as a cultivated fish has been chosen by many farmers because it is able to reproduce naturally and is relatively easy in its cultivation. Meanwhile, as a consumption fish, gouramy is quite popular because of its delicious and savory taste. Market demand for gouramy continues to increase at a high enough price. Economically, the selling price of gouramy is relatively stable (Tim Lentera, 2003). Purbalingga is one of the districts that has gouramy production as a regional commodity. This is evidence that this district is one of the centers for gouramy cultivation in the province of Central Java.

Morphological characters are commonly used for taxonomic studies of a species because different variations between individuals often indicate different species (Darwin, 1854; Pilsbry, 1916; Permadi, 2014). (Syoc, 2010) noted that Darwin saw species that varied morphologically as variations within a species to encourage speciation. Investigations down to the genetic level can help in distinguishing 2 species that cannot be resolved morphologically. Morphological parameters of Trichodina spp. including body diameter, denticle ring diameter, adhesive disc diameter, number of denticles and membrane width of Trichodina spp. The problem that arises is the large number of biased 
species (cryptic species) and this problem can be solved using molecular characters, however to identify an organism using molecular techniques has not been widely used. Several molecular techniques have been developed to trace the presence of a specific DNA sequence from a particular organism, for example the use of the 18S rRNA gene sequence to determine the relationship of an organism in general morphological features.

The 18S rRNA gene is often used for phylogenetic studies because it has conserved areas. The unique and conserved region can be used to characterize the organism concerned, so that it becomes the signature sequence of an organism. Likewise, the data on the nucleotide base of the $18 \mathrm{~S}$ rRNA gene allows it to be used in constructing a phylogenetic tree that shows the ancestry and kinship of an organism (Suwanto, 2011). Molecular research can complement the morphological identification of organisms. Partial amplification of the 18S rRNA gene can be used to specifically identify Trichodina paraheterodenta (Tang et al., 2013).

Research Problems are what are the morphological characters of Trichodina spp. morphometrically isolated from gouramy at BBI Kutasari Purbalingga and What is that infected gouramy larvae at BBI Kutasari Purbalingga using 18S RNA gene detection. The objectives to detect the Trichodina spp. 18S RNA gene. which infected larvae gouramy. Benefit providing information on the results of the detection of the putative 18S RNA gene of Trichodina sp. which infected larvae gouramy

\section{METHODS}

The tools used in this study were sample containers, tissue, gloves, masks, dissection kits, micropipettes, Erlenmeyer, digital scales, autoclaves, refrigators, freezers, PCR machines (PQLAB), electrophoresis kits, slide glass, vortex, microscopes, Cavity slide, centrifuge and water bath, camera. Tool specifications are in Appendix The materials used in this study were Trichodina sp. from Gouramy fish taken from BBI Kutasari Purbalingga, NLS (Nuclei Lysis Solution), Rnase Solution, PPS (Protein Precipitation Solution), Isopropanol, DNA Rehydration Solution, 70\% alcohol, TBE 1x, Agarose, EtBr, distilled water, gloves, Promega Kit, Master mix, PCR mix (Primer F, Primer R, template DNA, ddH2O), Microcrystal tips rack, Microcrystal tips 0.5-10ul, Yellow tips 200 ul, Blue tips 1000 ul, Microtube $1.5 \mathrm{ml}$.

The implementation of this research was carried out from May to July 2017. Sampling of the research will be carried out at the Kutasari Purbalingga Fish Seed Center. Research observations will be carried out at the Parasitology Laboratory and the Genetics and Molecular Laboratory, Faculty of Biology, Jenderal Soedirman University.

\section{Sampling Technique}

This research will be conducted using a survey method with purposive sampling technique. The gouramy which was taken from BBI Kutasari Purbalingga was put into plastic container then taken to the Laboratory of Parasitology, isolated and taken ectoparasite species Trichodina spp. only, whose characteristics are known by reference. Sampling was done once. Samples were taken in genomic DNA isolation at the Molecular Laboratory of the Faculty of Biology, Jenderal Soedirman University and carried out DNA extraction and PCR. Trichodina was isolated from the caudal fin of Gurami (Osphronemus goramy) to obtain its DNA through the extraction method, DNA amplification using PCR (Polymerase Chain Reaction) techniques using universal primers. Then, DNA Visualization uses electrophoresis techniques.

\section{Molecular Identification}

Genomic DNA Isolation of Trichodina sp.DNA Trichodina sp. extracted from the gouramy fin tissue. DNA extraction method with working steps:

1. Pellets (Trichodina sp.) are added $600 \mu \mathrm{l}$ of Nuclei lysis Solution into tube 1.5 (homogeneous for 10 seconds)

2. $3 \mu \mathrm{l}$ of RNAse was added to the tissue which had been given Nuclei Lysis solution after that it was homogenized

3. Incubate in a water bath at $37^{\circ} \mathrm{C}$ for $5-10$ minutes

4. Added $200 \mu \mathrm{l}$ of Protein Prespitation Solution

5. Vortex for 10 seconds

6. Incubate in the refrigerator at $-20^{\circ} \mathrm{C}$ for 5 minutes

7. Centrifugation at $4^{\circ} \mathrm{C}$ at $13,000 \mathrm{rpm}$ for 4 minutes

8. The supernata at the top was taken and then transferred into a new 1.5 tube

9. Add $600 \mu \mathrm{l}$ of isopropanol to the tube that has been moved (homogeneous by means of back and forth)

10. Centrifugation 13,000 for 1 minute at $4{ }^{\circ} \mathrm{C}$

11. Supernata at the top are removed

12. The supernata below are added with $600 \mu \mathrm{l}$ of $70 \%$ Ethanol (homogenized)

13. Centrifuge at $4{ }^{\circ} \mathrm{C} 13,000 \mathrm{rpm}$ for 1 minute

14. Ethanol removed and dried for 30 minutes

15. Add $100 \mu \mathrm{l}$ of DNA Rehydration solution then incubate at $20^{\circ} \mathrm{C}$ (over night)

\section{Amplification of the 18S rRNA gene using PCR technique}

The amplification of the 18S rRNA gene from Trichodina paraheterodentata was carried out using PCR techniques. The primers used were Forward primers (5 '-AAC CTG GTT GAT CCT GCC ATG3') and Reverse primers (5 '-TGA TCC TTC TGC AGG TTC ACC TAC-3') which produced 600 bp DNA amplicons (Tang et al., 2013). The gene amplification procedure uses the PCR technique with the following steps:

1. Preparation of PCR mixture (PCR mix) in a volume of $15 \mu \mathrm{l}$ in an eppendorf tube $(1.5 \mathrm{ml})$ with the composition in Table 1. 
Table 1. PCR mixture composition

\begin{tabular}{clr}
\hline No. & \multicolumn{1}{c}{ Metrials } & Volume $(\mu \mathrm{l})$ \\
\hline 1 & Master Mix & 7.5 \\
2 & Forward Primer $(15 \mu \mathrm{M})$ & 0.25 \\
3 & Reverse Primer $(15 \mu \mathrm{M})$ & 0.25 \\
4 & ddH2O & 4 \\
5 & Template DNA & 3 \\
& Total & 15
\end{tabular}

* Does not take concentration measurements.

2. Amplification was carried out on a Thermocycler (PeqLab) machine with PCR conditions used to amplify 35 cycles of $18 \mathrm{~S}$ rRNA genes, as follows: pre-denaturation stage at $95^{\circ} \mathrm{C}$ for 5 minutes, denaturation at $95^{\circ} \mathrm{C}$ for 1 minute, annealing at $61^{\circ} \mathrm{C}$ for 1 minute 30 seconds, extension at $72^{\circ} \mathrm{C}$ for 1 minute, and post-extension at $72^{\circ} \mathrm{C}$ for 5 minutes (Folmer, 1994).

3. Visualization of DNA amplicons using agarose gel electrophoresis technique $(1 \%)$ resulted in DNA amplicons measuring $600 \mathrm{bp}$.

\section{Data Analyses}

Positivity of the DNA amplicon of $18 \mathrm{~S}$ rRNA gene from the study sample

\section{RESULT AND DISCUS}

The morphology of the body parts of Trichodina paraheterodentata shows several features and varying shapes of denticles, namely having a blunt blade apex tip and a straight tapered but thicker denticle ray shape. Trichodina paraheterodentata research results were found in gouramy seeds on the tail fin. According to Basson \& Van As (2006), Trichodina paraheterodentata is found mostly on the skin surface and is rarely found in gills. Meanwhile, research by Rokhmani et al. (2015) on the type of Trichodina sp. The gouramy seeds in Banyumas, Banjarnegara and Purbalingga are Trichodina sp. those found were Trichodina nobilis, Trichodina reticulata. Tichodina acuta, Trichodina paraheterodentata, Trichodina magna, Trichodina pediculus, and Trichodina nigra (Rokhmani et al., 2015).

Trichodina spp. are spherical and supported by a rigid ring of interconnected discs called chitinoids (Durborow, 2003). The ability to infect Trichodina spp., In fish seeds is related to the structure and morphology of the denticle ring of
Trichodina spp. (Kabata, 1985). The structure and morphology of the denticle rings are the morphometric characters of Trichodina spp. which can be used to determine the type of Trichodina spp. One of the morphometric size characters of Trichodina spp. in the form of a denticle tip. The denticle tips of Trichodina spp. There are two types, namely sharp and blunt (Windarto et al., 2013).

Morphological characteristics of Trichodina spp. In gouramy seeds, there are known differences in the characteristics of the size of the body diameter, denticle ring diameter, adhesive disc diameter, number of denticles and membrane width. Types of Trichodina spp. Research results can be identified based on Duncan (1977); Padua et al., (2012); Lom (1961) in Basson (2010); Albaladejo \& Arthur (1989) in Dana et al., (2002); Van \& Basson (1986) in Woo (2006). According to Duncan (1977); Padua et al. (2012), Trichodina paraheterodentata has a characteristic body diameter of 71-106 $\mu \mathrm{m}$; denticle ring diameter 26-37 $\mu \mathrm{m}$; adhesive disc diameter 47 $63 \mu \mathrm{m}$; the number of denticles 20-27; membrane width $2.7 \mu \mathrm{m}$. Meanwhile, according to Van and Basson (1986) in Woo (2006), Trichodina paraheterodentata has a characteristic adhesive disc diameter of 38-82 $\mu \mathrm{m}$; denticle ring diameter 23-51 $\mu \mathrm{m}$; the number of denticles 20-30. According to Albaladejo \& Arthur (1989) in Dana et al., (2002), the type of Trichodina paraheterodentata has a characteristic body diameter of 53.0-71.5 $\mu \mathrm{m}$ (57.9 $\mu \mathrm{m} \pm 3.7)$; denticle ring diameter 24.5-41.2 $\mu \mathrm{m}(35$ $\mu \mathrm{m} \pm 4.2)$; adhesive disc diameter 44.0 - $61.0(52.1 \pm$ $5.4)$; the number of denticles $20-24(21.8 \pm 1.2)$ and a membrane width of $4.0-6.5 \mu \mathrm{m}(5.5 \mu \mathrm{m} \pm 0.6)$.

The results Amplification of the 18S RNA gene in Trichodina sp. from Purbalingga was done using the PCR method. The interpretation can be seen in Figures 1 to 4 . Each band on the gel indicates the presence of Trichodina paraheterodentata. 


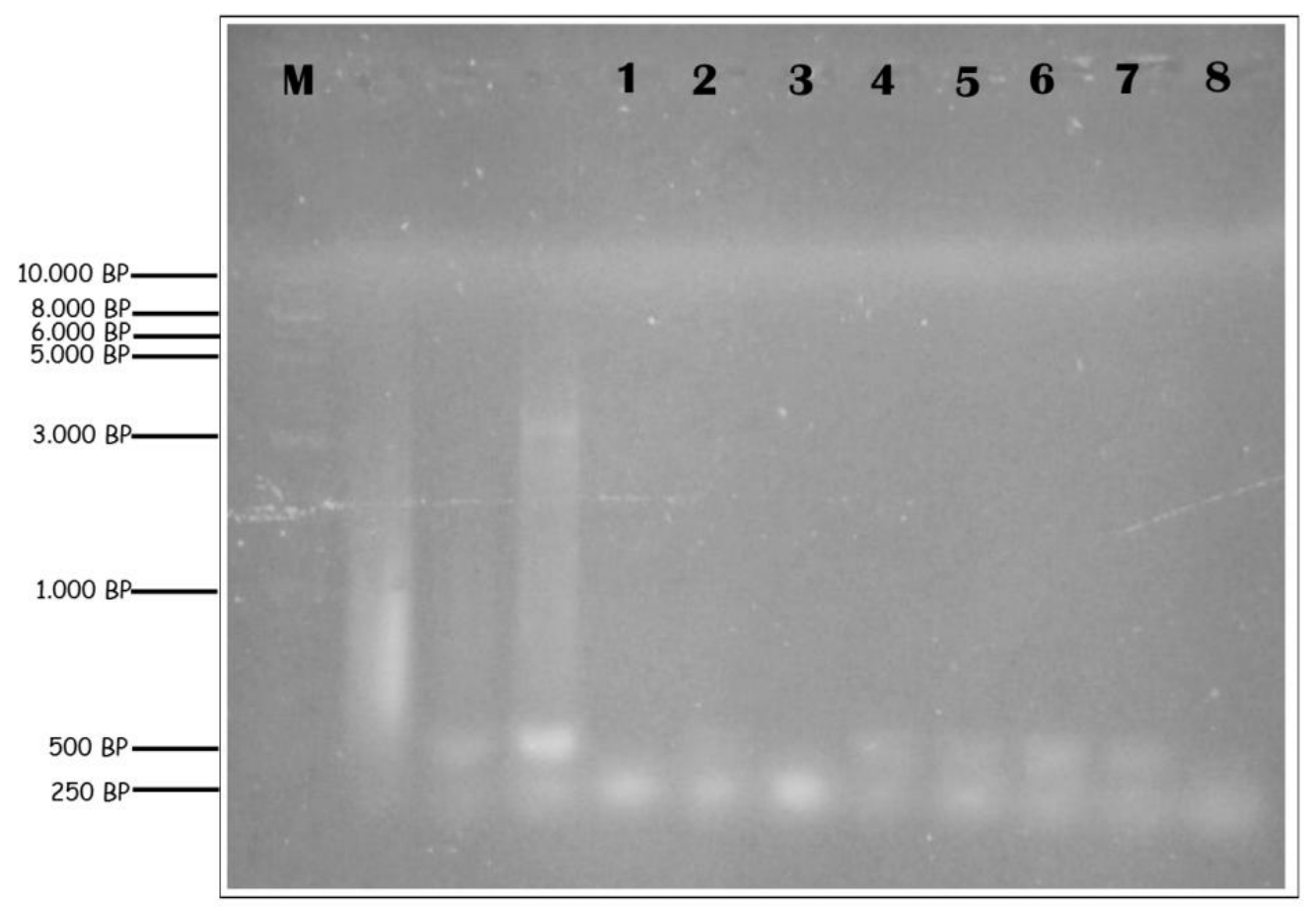

Figure 1. Results of DNA extraction from Trichodina spp. on Gouramy fish at BBI Kutasari Purbalingga. Note : (M = Marka, 1 = Purbalingga 1, $2=$ Purbalingga 2, $3=$ Purbalingga 3, $4=$ Purbalingga 4, $5=$ Purbalingga 5, $6=$ Purbalingga 6, $7=$ Purbalingga 7, $8=$ Purbalingga 8 ).

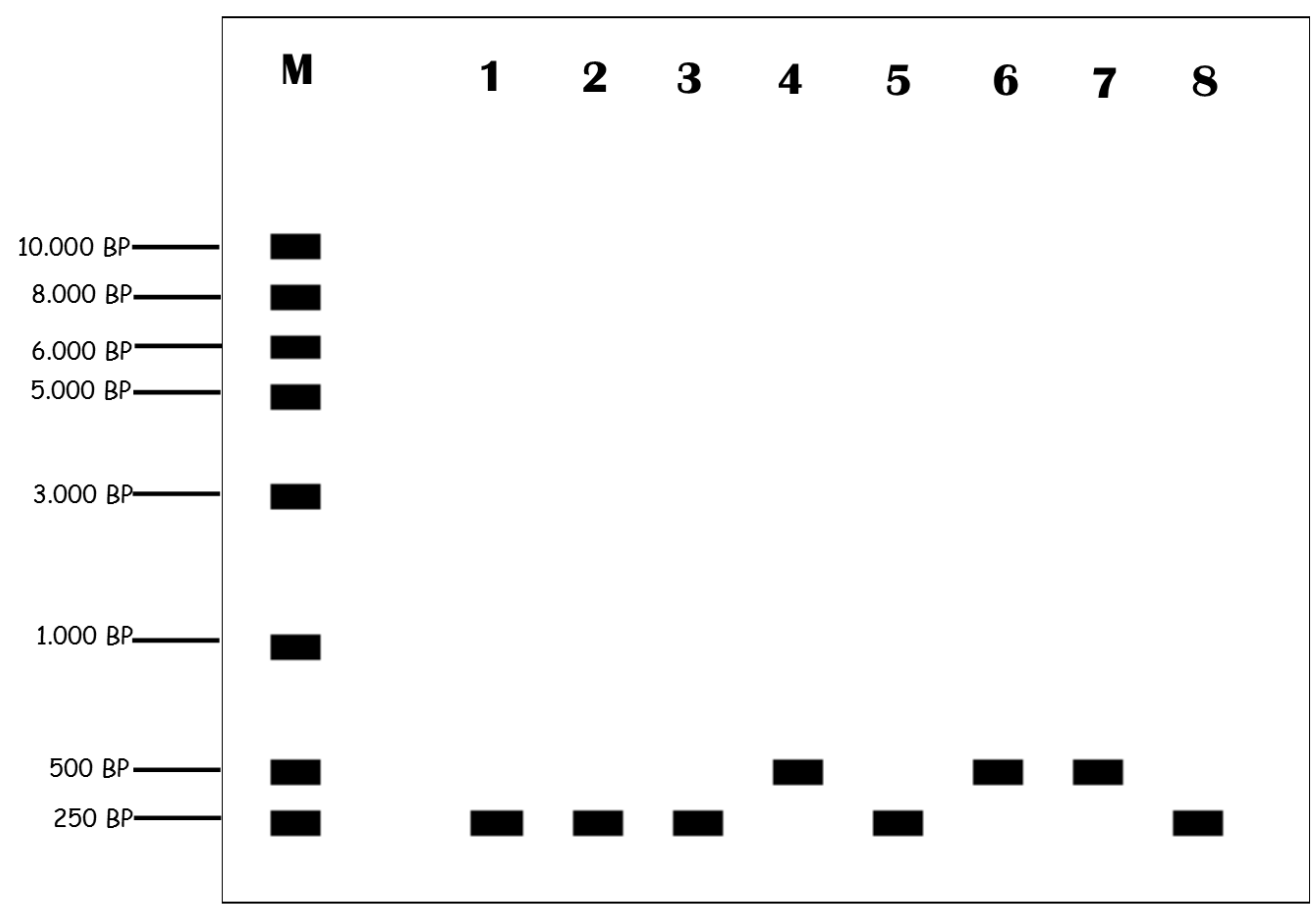

Figure 2. Interpretation of the extracted DNA from Trichodina spp. on Gouramy fish at BBI Kutasari Purbalingga.

Note : $(M=$ Marka, $1=$ Purbalingga 1, $2=$ Purbalingga 2, $3=$ Purbalingga 3, $4=$ Purbalingga 4, $5=$ Purbalingga 5, $6=$ Purbalingga 6, $7=$ Purbalingga 7, $8=$ Purbalingga 8 ). 


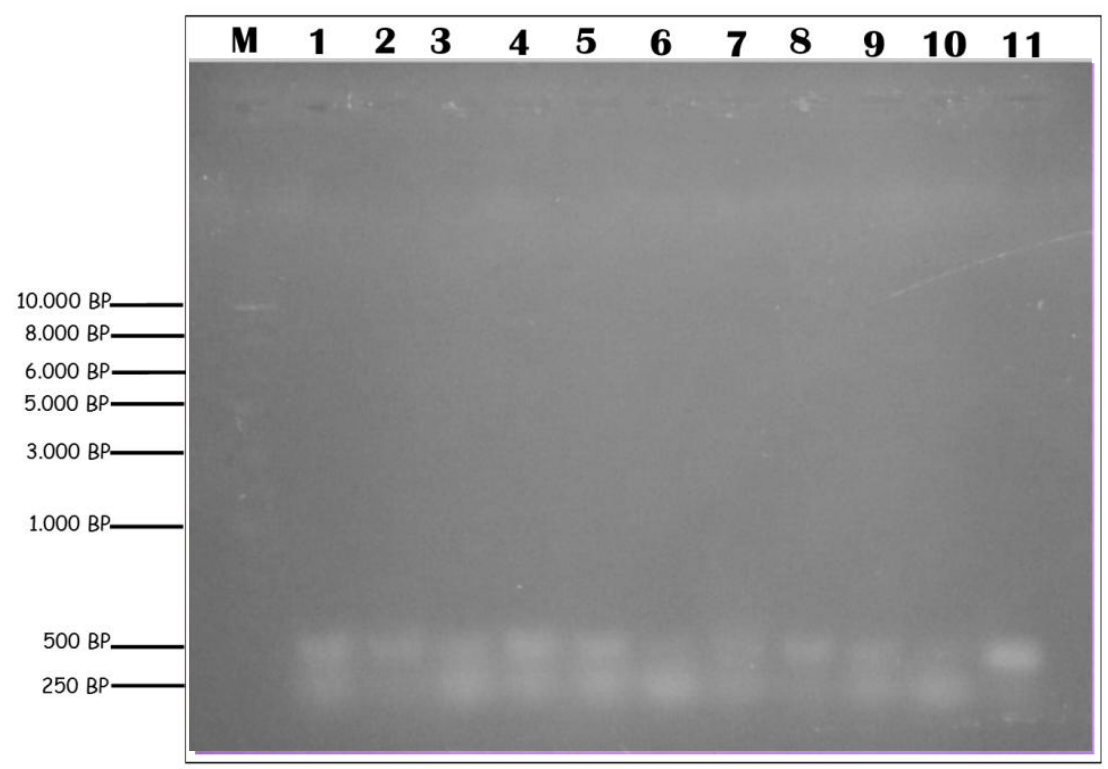

Figure 3. Results of DNA extraction from Trichodina spp. on Gouramy fish at BBI Kutasari Purbalingga. Notes : $(\mathrm{M}=$ Marka, $1=$ Purbalingga $1,2=$ Purbalingga 2, $3=$ Purbalingga $3,4=$ Purbalingga $4,5=$ Purbalingga 5, $6=$ Purbalingga $6,7=$ Purbalingga 7, $8=$ Purbalingga $8,9=$ Purbalingga 9, $10=$ Purbalingga 10).

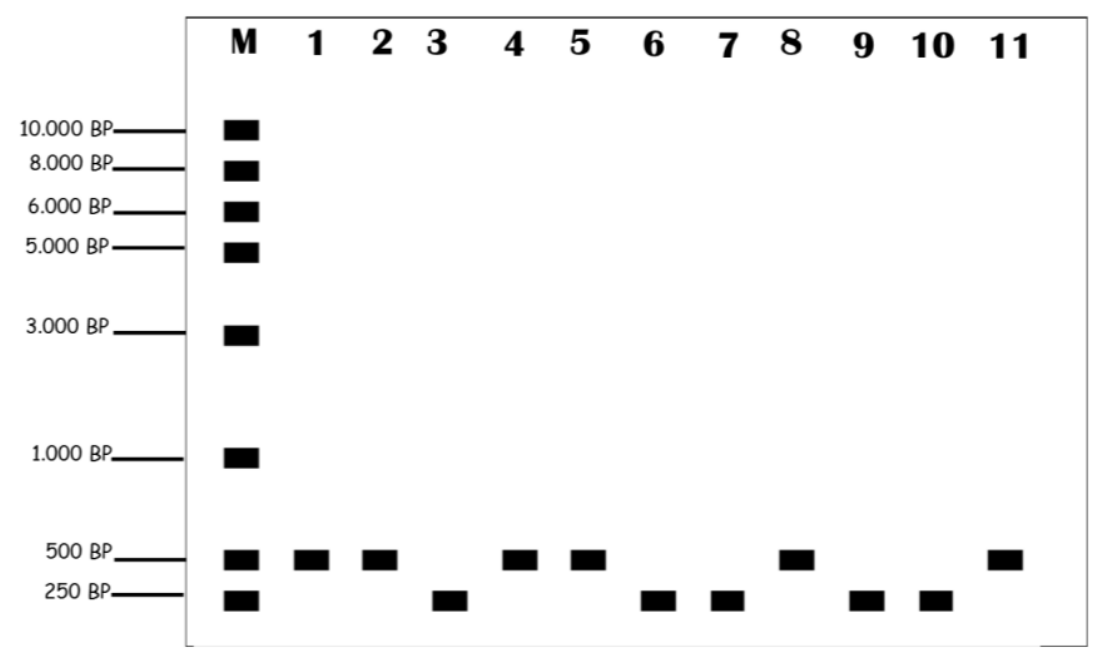

Figure 4. Interpretation of the extracted DNA from Trichodina spp. on Gouramy fish at BBI Kutasari Purbalingga.

$(\mathrm{M}=$ Marka, $1=$ Purbalingga 1, $2=$ Purbalingga 2, $3=$ Purbalingga 3, $4=$ Purbalingga 4, $5=$ Purbalingga 5, $6=$ Purbalingga 6, $7=$ Purbalingga 7, $8=$ Purbalingga 8, $9=$ Purbalingga 9, $10=$ Purbalingga 10) .

The results of DNA isolation visualized on agarose gels in Figures 1 and 4 produced 19 DNA bands measuring 250 - $500 \mathrm{bp}$, all DNA bands showed the presence of Trichodina paraheterodentata in gouramy taken from BBI Kutasari Purbalingga. The entire DNA band is contaminated (smear), appears due to the presence of RNA contaminants or nuclease. The intact DNA is characterized by the absence of an electrophoretic DNA smear. This is important because in the PCR process, the intact DNA will provide relatively more accurate results (Syafaruddin \& Tri, 2011).
Detection of the 18S rRNA gene in Trichodina spp. $10 \%$ Trichodina paraheterodentata is found in gouramy seeds belonging to BBI Strongasari Purbalingga. This result is low, when compared to the research of Rokhmani (2017) which detected the 18S rRNA gene in gouramy seeds belonging to Banjarnegara Rakit fish farmers, which was $45 \%$. Based on the environmental conditions between the two sampling locations, BBI Kutasari Purbalingga is quite good, while in the Rakit Banjarnegara fish farmer the environment is less or bad enough. Observations on the maintenance of gouramy seeds at BBI Kutasari Purbalingga show 
that the aquatic environment is good enough so that it does not support parasites to breed. According to Syafaruddin \& Tri (2011), Trichodina spp. can reproduce rapidly, has a wide spread, and is a parasite commonly found in freshwater fish and can infect various types of fish. Incidence of infection with Trichodina sp. The host is influenced by water quality and poor pond maintenance techniques, namely high stocking density and calm, inundated and non-flowing ponds. The high stocking density will cause the fish to come into contact with each other so that parasites will be easily transmitted to other fish.

\section{CONCLUSION}

Based on the results and discussion that has been described, it can be concluded that, The morphological description of Trichodina spp. identified was Trichodina paraheterodentata and the detection percentage of the $18 \mathrm{~S}$ rRNA gene for the protozoan species Trichodina paraheterodentata that infected the gouramy seeds from Purbalingga was $10 \%$. The percentage of detection of this gene was low when compared to the results of the detection of the 18S rRNA Trichodina paraheterodentata gene that infected Banjarnegara gouramy seeds (45\%).

\section{ACKNOWLEDGEMENT}

We would like to deliver our greatest gratitude, especiallyfor the Dean of Biology Faculty, as well as the head of entomology and parasitology including my staffs and students who provide assistance and contributions in this study. We would also like to thank the Head of Unsoed Reseach Centre for providing funds through the scheme of Competence Research BLU Unsoed No : 1248/UN23.14/PN.01.00/ 2017, February 3, 2017.

\section{REFERENCES}

Albaladejo, J.D. \& J.R. Arthur. 1989. Some Trichodinids (Protozoa: Ciliophora: Peritrichida) from Fresh Water Fishes Inported into The Philippines. Asian Fisheries Science, 3(1), pp. 1 -25.

Arthur, J.R. \& J. Lom. 1984. Trichodinid Protozoa (Ciliophora: Peritrichida) from Fresh Water Fishes of Rybinsk Reservoir. USSR. Journal of Protozoology, 31(1), pp. 82-91.

Basson, L. \& Van As, J.G. 2006. Trichodinidae and Other Ciliophorans (Phyllum Ciliopora). In Woo, P.T.K (Ed), Fish Diseases and Disorders, Volume 1: Protozoan and Metazoan. Second Edition. London: CAB International Publishing, 5(1), pp. 154-182.

Basson, L. 2010. First records of Trichodinid ectoparasites (Ciliophora: Peritrichia) from included freshwaterfishes in Tasmania, Australia, with comments of Pathogenity. Acta Parasitologica, 49(3), pp. 253-265.
Duncan, B. 1977. Urceolariid ciliates, including three new species, from cultured Philippine fishes. Trans. Amer. J Micros. Soc, 96(1), pp. 76-81.

Felsentein, J. 1978. Case in Wich Parsimony or Compatibility Methods Will Be Positively Misleading. Systematic Zoology, 27(4), pp. 401-410.

Fernando, C.H., Furtado, J.1., Gusse, A.V., Harek \& kakoge, A. 1972. Method for the Study of Freshwater Fish Series. Canada: University of Waterloo.

Gargas, J. 1995. Internal Parasites of Fish: Cestode, Digneans, and Nematodes. J FAMA, 2(1), pp. 95.

Handayani, R., Adiputra, Y.T., \& Wardiyanto. 2014. Identifikasi dan Keragaman Parasit pada Ikan Mas Koki (Carrasius auratus) dan Ikan Mas (Cyprinus carpio) yang Berasal dari Lampung dan Luar Lampung. Jurnal Ilmu Perikanan dan Sumberdaya Perairan.

Handoyo, D., \& Ari, R. 2000. Prinsip Umum dan Pelaksanaan Polymerase Chain Reaction (PCR) [General Principles and Implementation of Polymerase Chain Reaction]. Unitas, 9(1), pp. 17-29.

Irianto, A. 2005. Patologi Ikan Teleostei. Yogyakarta : Gadjah Mada University Press.

Kabata, Z. 1985. Parasites and Diseases of fish Cultured In The Tropics. London: Taylor and Franscis.

Lom, J. 1962. Trichodinid ciliates from fishes of the Rumanian Black Sea Coast. Journal of Parasitology, 52(1), pp. 49-61.

Louie, M., Louie L., Simor A.E. 2000. The Role of DNA Amplification Technology in the Diagnosis of Infectious Disease. Can Med Assoc J, 9(1) , pp. 163-201.

Margolis, L. \& Arthur, J.K. 1979. Synopsis of the Parasites of Fishes of Canada. Fish. Res. Board Can. Bull, 199(1), pp. 1-269.

McArdle, J.F. 1984. Trichodina as A Cause of Mortalities in Cange Reared Rainbow Trout (Salmo gairdneri) and Salmon (Salmo salar). Bulletin Europe Fish Pathology, 4(1), pp. 3-6.

Nuryanto, A., Pramono, H., \& Sastranegara, M.H. 2017. Molecular Identification of Fish Larvae from East Plawangan of Segara Anakan Cilalcap, Central Java Indonesia . Jurnal Biosaintifika: Journal of Biology \& Biology Education, 9, pp. 33-40.

Nugrayani, D., Agung, C.S., \& Hamdan, S. 2011. Prevalensi Trichodina Pada Kondisi Lingkungan Perairan Berbeda. J OmniAkuatika, 3(13), pp. $43-48$. 
Pramono, T.B \& H. Syakuri. 2008. Infeksi Parasit Pada Permukaan Tubuh Ikan Nilem (Osteocillus hasellti) yang Diperdagangkan Di PPI Purbalingga. Berkala Ilmiah Perikanan, 3 (2), pp. 1-15.

Rokhmani. 2009. Keragaman dan Tingkat Serangan Ektoparasit pada Gurame (Osphronemus gouramy Lac.) Tahap Pendederan I dengan Ketinggian Lokasi Pemeliharaan yang Berbeda. Jurnal Biotika, 7 (2), pp. 87-93.

Rokhmani, Edy Purwonohadi dan Siti Khasanah, 2015. Hubungan Kekerabatan protozoa Trichodina sp yang menginfeksi benih gurame dari sentra pembenihan di Jawa Tengah dan Pengendaliannya. Proseding Semnas - LPPM 5, Unsoed Purwokerto.

Rokhmani, Edy, R., Endang, A., Darsono \& Daniel D.W. 2016. Hubungan Kekerabatan protozoa Trichodina sp yang menginfeksi benih gurame dari sentra pembenihan di Pulau Jawa dan Pengendaliannya. Proseding Semnas LPPM 6. Unsoed Purwokerto.

Scholz, T., 1999. Parasite in Cultured and Feral Fish. Jerman: Veterinary Parasitology.

Suwanto, A. 2011. Keanekaragaman Hayati Mikroorganisme. Bogor: Jurusan Biologi FMIPA IPB.

Syafaruddin \& Tri J. S., 2011.Optimasi Teknik Isolasi dan Purifikasi DNA yang Efisien dan Efektif pada Kemiri Sunan (Reutalis trisperma (Blanco) Airy Shaw). JLittri, 17(1), pp. 11-17.
Tang, F-H, Zao, Y-J, Waren A. 2013. Phyolgenic analysis of Thricodinids (Cilliophora, Oligohymenophora) inferred from 18S rRNA gene sequence data. Curr Microbiol, 66 (1), pp. 306-311.

Tim Lentera., 2003. Cepat dan Tepat Memasarkan Gurami. Jakarta : AgroMedia Pustaka.

Van, A.J. G. \& Basson, L. 1986. Trichodinid (Ciliophora: Peritrichida) Ectoparasites of Cultured Cichlids from Taiwan. Bulletin Institute. Zoology Academy Sinica, 25 (1), pp. 135-139.

Van, A.J.G., L. Basson \& J. Theron. 1984. An Experimental Evaluation of The Use of Formalin to Control Trichodiniasis and Other Ectoparasitic Protozoan on Fry of Cyprinus Carpio L. and Oreochromis Mossambicus (Peters). South African Journal of Wildlife Research, 13 (1), pp. 42-48.

Windarto, R., Adiputra, Y.T., Wardiyanto \& Efendi E., 2013. Keragaman Karakter Morfologi Antara Trichodina Nobilis dan Trichodina Reticulata pada Ikan Komet (Carrasius Auratus). e-Jurnal Rekayasa dan Teknologi Budidaya Perairan, 1(2), pp. 117-126.

Woo, J.L. 2006. Fish Disease and Disorder Parasite. University of Guelph. Canada: CAB. International. 